\title{
Detection of Brazilian Hantavirus by Reverse Transcription Polymerase Chain Reaction Amplification of N Gene in Patients with Hantavirus Cardiopulmonary Syndrome
}

\author{
Marcos Lázaro Moreli, Ricardo Luiz Moro de Sousa, Luiz Tadeu Moraes Figueiredo+
}

Unidade Multidepartamental de Pesquisa em Virologia, Faculdade de Medicina de Ribeirão Preto, Universidade de São Paulo, Av. Bandeirantes 3900, 14049-900 Ribeirão Preto, SP, Brasil

We report a nested reverse transcription-polymerase chain reaction (RT-PCR) assay for hantavirus using primers selected to match high homology regions of hantavirus genomes detected from the whole blood of hantavirus cardiopulmonary syndrome (HCPS) patients from Brazil, also including the $\mathrm{N}$ gene nucleotide sequence of Araraquara virus. Hantavirus genomes were detected in eight out of nine blood samples from the HCPS patients by RT-PCR (88.9\% positivity) and in all 9 blood samples (100\% positivity) by nested-PCR. The eight amplicons obtained by RT-PCR (P1, P3-P9), including one obtained by nested-PCR (P-2) and not obtained by RT-PCR, were sequenced and showed high homology (94.8\% to 99.1\%) with the $N$ gene of Araraquara hantavirus. Although the serologic method ELISA is the most appropriate test for HCPS diagnosis, the use of nested RT-PCR for hantavirus in Brazil would contribute to the diagnosis of acute hantavirus disease detecting viral genomes in patient specimens as well as initial genomic characterization of circulating hantaviruses.

Key words: hantavirus cardiopulmonary syndrome - nested RT-PCR - N gene of hantavirus

Since it was described in 1993, hantavirus cardiopulmonary syndrome (HCPS) has been reported in virtually the entire American Continent. Presently, most of the reported HCPS cases are from South America, where the Andes strain of hantavirus is responsible for the majority of the cases (Nichol et al. 1993, Padula et al. 2000a).

Hantavirus is a genus within the Bunyaviridae family. These viruses are enveloped negative-stranded RNA virus with a tripartite negative-sense RNA genome whose segments are designated L, M, S, respectively coding for the polymerase associated to the virion, two surface glycoproteins (G1 and G2), and the nucleocapsid protein (N) (Schmaljohn 1996).

The evolution of the American hantaviruses has an intimate relationship with the evolution of rodent reservoirs, which are classified in Rodentia order, Muridae family and Sigmodontinae sub-family (Schmaljohn \& Hjelle 1997, Zhao \& Hay 1997). Humans are infected through the respiratory route by contact with rodent excretions and secretions. However, during an outbreak in Argentina caused by Andes virus, person-to-person transmission was described (Wells et al. 1997).

A hantavirus was isolated for the first time in Brazil from Rattus norvegicus in the northern region of the state of Pará, in 1982 (Le Duc et al. 1985). In 1993, three HCPS cases were detected in members of one family who lived in a farm in close contact with wild rodents, in Juquitiba, SP, Southeast Brazil. Two of these three patients died.

Financial support: Fundação de Amparo à Pesquisa do Estado de São Paulo

${ }^{+}$Corresponding author. Fax: + 55-16-633.6695. E-mail. ltmfigue@fmrp.usp.br

Received 21 October 2003

Accepted 30 August 2004
Between 1993 and December 2003, about 329 HCPS cases were reported in Brazil (Iversson 1996, Funasa 2003). HCPS occurred in people of both sexes, aged 9 months to 66 years, with a $40 \%$ case fatality rate. Most of the HCPS cases in Brazil occurred in the Southern and Southeastern regions (Funasa 2003).

Several hantaviruses have been detected in South America, such as Andes (Lopez et al. 1997), Laguna Negra (Johnson et al. 1997), Rio Mamoré (Bharadwaj et al. 1997), and Caño Delgadito (Fulhorst et al. 1997). To assess the degree of genomic variability of these viruses, partial nucleotide sequences of the $\mathrm{M}$ and $\mathrm{S}$ viral RNA segments were analyzed (Padula et al. 2000a). These studies showed that HCPS patients from Argentina, Chile, Paraguay, Uruguay were infected with the lineages Andes or Laguna Negra. Rio Mamore, a hantavirus isolated in Iquitos, Peru, showed a closer relationship with Laguna Negra than with Andes virus based on phylogenetic analysis of the complete $S$ segment (Bharadwaj et al. 1997).

Partial nucleotide sequences of the N, G1, G2 genes obtained from acute-phase serum samples from 3 HCPS patients from Castelo dos Sonhos, state of Mato Grosso, in Central Brazil, and from Araraquara and Franca, state of São Paulo, in Southeast Brazil, were analyzed (Johnson et al. 1999). In the phylogenetic analysis based on nucleotide and deduced amino acid sequences, the identity between Araraquara and Franca viruses revealed to be high and the three Brazilian hantaviruses appeared to be more closely related to the Argentinean Andes virus.

HCPS has become a public health problem in Ribeirão Preto City and neighboring towns in the state of São Paulo, Brazil (Johnson et al. 1999, Figueiredo et al. 1999). In the last 5 years, 29 cases of HCPS were reported in the region of Ribeirão Preto with a $48 \%$ fatality rate (Funasa 2003). Clinical samples from nine of these patients were analyzed in the present study. 
The diagnosis of hantavirus infections in Brazil has been confirmed only by the detection of IgM antibodies against Sin Nombre virus by ELISA serologic test using recombinant $\mathrm{N}$ protein provided by Center for Diseases Control (CDC, US), or immunohistochemistry carried out at Instituto Adolfo Lutz, São Paulo (Ksiasek et al. 1995, Zaki et al. 1995). Also was used in the ELISA a recombinant $\mathrm{N}$ protein from Andes virus provided by Carlos Malbran Institute, Buenos Aires, Argentina (Padula et al. 2000b). These have been the only available tests, and it is done in only three centers (Adolfo Lutz, Evandro Chagas, Oswaldo Cruz Institutes), due to difficulties to obtain hantavirus antigens that are not produced in the country. As an alternative diagnostic method, virus detection in patient specimens can be performed by reverse transcription-polymerase chain reaction (RT-PCR) amplification, an efficient method first described for HCPS diagnosis in 1993 (Le Guenno 1993, Kim et al. 1994, Johnson et al. 1999, Garin et al. 2001). Although this molecular technique has been applied as an alternative diagnostic method, serologic test (ELISA) can and must be the method of choice for the diagnosis of this zoonosis, because in the public health, ELISA is the most appropriate test for HCPS diagnosis. We report here the detection of Brazilian hantavirus genome in human blood samples from HCPS patients by a nested RT-PCR. In addition, we report a phylogenetic analysis of nucleotide sequences of hantavirus $\mathrm{N}$ gene obtained from HCPS patients.

\section{MATERIALS AND METHODS}

Blood samples of HCPS patients and controls for the nested RT-PCR - Whole blood samples from nine patients (P) with HCPS from Ribeirão Preto area, state of São Paulo, Brazil (Table I), were processed for hantavirus genome detection by nested RT-PCR. All 9 P had HCPS diagnosis confirmed by the detection of $\operatorname{IgM}$ antibodies to Sin Nombre virus antigens (CDC, US) in an ELISA done by the Adolfo Lutz Institute, São Paulo City, Brazil (Ksiasek et al. 1995). The blood samples remained stored for 3 months to 3 years, at $-70^{\circ} \mathrm{C}$. A plasmid (pET23b) containing the $\mathrm{N}$ gene of Andes hantavirus was kindly supplied by Dr Brian Hjelle, New Mexico, US. This plasmid was propagated in Escherichia coli, purified with the Plasmid Mini Kit (Qiagen, Germany) and used as a positive control in the nested RT-PCR assay. Water and a blood sample from a patient with dengue were used as negative controls.

RNA extraction - RNA was extracted from $300 \mu \mathrm{l}$ of each hemolysed whole blood sample, which was mixed with $1 \mathrm{ml}$ of Trizol LS reagent (Gibco, US), and $200 \mu$ of chloroform-isoamyl alcohol (24:1) according to modifications described previously by Bowen et al. (1997). Pellets were suspended in 10 to $20 \mu \mathrm{l}$ of diethyl pyrocarbonate (DEPC) treated water.

RT-PCR primers - Nucleotide sequences of the $\mathrm{N}$ gene of the South American hantaviruses, Andes, Rio Mamoré, Araraquara, and Castelo dos Sonhos were aligned by the Higgins and Sharp algorithm, using default stringency parameters as recommended by the DNASIS for Windows version 2.10 software (Hitachi, Japan). After alignment of the hantaviruses nucleotide sequences two primers for RT-PCR were designed in highly conserved regions in the $\mathrm{N}$ gene (SAHN-C and SAHN-S, Table II) to amplify a region of 264 nucleotides.

$R T$-PCR - For the reverse transcription (RT), a $20 \mu \mathrm{l}$ volume reaction mixture containing $5 \mu 1$ of the RNA extract, $1 \mu 1$ of $2.5 \mathrm{mM}$ deoxyribonucleoside triphospfates (dNTPs), $0.3 \mu \mathrm{M}$ of the SAHN-C primer, and $4 \mu \mathrm{l}$ of RT $5 \mathrm{x}$ buffer (10mM Tris pH 8.9, $\left.1.5 \mathrm{mM} \mathrm{MgCl}_{2}, 80 \mathrm{mM} \mathrm{KCl}\right)$ was prepared. The mixture was overlaid with two drops of min-

TABLE I

Hantavirus cardiopulmonary syndrome patients whose blood samples were tested by nested-polymerase chain reaction

\begin{tabular}{lccllcl}
\hline Patient & Sex & Age (years) & Risk activity & Disease onset & Sampling day & Evolution \\
\hline 1 & M & 55 & Agricultural worker & May, 1998 & 3 days & Death \\
2 & M & 38 & Farmer & June, 1998 & 3 days & Death \\
3 & M & 29 & Truck driver & May, 1999 & 5 days & Survived \\
4 & M & 26 & Farmer & May, 1999 & 3 days & Death \\
5 & $F^{\text {c }}$ & 13 & Student & June, 1999 & 8 days & Survived \\
6 & M & 21 & Agricultural worker & April, 2001 & 9 days & Survived \\
7 & M & 39 & Agronomist & August, 2002 & 3 days & Survived \\
8 & F & 31 & Nurse & April, 2002 & 4 days & Death \\
9 & M & 41 & Bootmaker & & & Survived \\
\hline
\end{tabular}

M: male, F: female; $a$ : sample collection days after the onset of symptoms

TABLE II

Primers used in the Brazilian hantavirus reverse transcription polymerase chain reaction (PCR) and nested-PCR

\begin{tabular}{lll}
\hline Primer & Nucleotide sequence & Annealing site \\
\hline SAHN-S (sense) & GATGAATCATCCTTGAACCTTAT & Nucleotide 477 to $454^{a}$ \\
SAHN-C (complementary) & CAAAACCAGTTGATCCAACAGGG & Nucleotide 213 to 236 a \\
SAHNinternal-S (sense) & GTTGACAGCATATATAAGGCCTT & Nucleotide 391 to 414 \\
SAHNinternal-C (complementary) & GATATGGGAATGTGCTGGATGT & Nucleotide 277 to 298 \\
\hline
\end{tabular}

$a$ : annealing site based on Araraquara virus. 
eral oil and heated at $95^{\circ} \mathrm{C}$ for $3 \mathrm{~min}$, in order to produces RNA linearization. After temperature reduction to $4^{\circ} \mathrm{C}$, $10 \mathrm{U}$ of RNAse inhibitor (Pharmacia, US) and $10 \mathrm{U}$ of reverse transcriptase MMLV (Pharmacia) were added to the RT reaction mixture, which was incubated for $2 \mathrm{~h}$ at $37^{\circ} \mathrm{C}$. The resulting cDNA was used as a template in the subsequent PCR reaction. For the PCR, a $50 \mu 1$ mixture containing $0.3 \mu \mathrm{M}$ of each SAHN-C and SAHN-S primers, $1 \mu \mathrm{l}$ of $2.5 \mathrm{mM}$ of the dNTPs, $3 \mu \mathrm{l}$ of the RT product, and $5 \mu \mathrm{l}$ of the $10 x$ buffer (10 $\mathrm{mM}$ Tris $\mathrm{pH} 8.9,1.5 \mathrm{mM} \mathrm{MgCl}_{2}, 80 \mathrm{mM}$ $\mathrm{KCl}$ ) was prepared. Finally, after heating at $80^{\circ} \mathrm{C}, 1 \mathrm{U}$ of thermostable Taq DNA polymerase (Pharmacia) was added and the mixture was submitted to 35 cycles in a thermal cycler (Iwaki, Japan), at the following temperatures: $95^{\circ} \mathrm{C}$ for $30 \mathrm{~s}, 55^{\circ} \mathrm{C}$ for $45 \mathrm{~s}$, and $72^{\circ} \mathrm{C}$ for $180 \mathrm{~s}$. Finally, the mixture was held for $5 \mathrm{~min}$ at $72^{\circ} \mathrm{C}$. Eight $\mu$ l of the amplified DNA was electrophoresed in $1.7 \%$ agarose gels in TAE buffer and stained with ethidium bromide $(1 \mu \mathrm{g} / \mathrm{ml}$ in water solution). DNA was visualized by using a $312 \mathrm{~nm} \mathrm{UV}$ transilluminator and camera. Amplicon sizes were determined by comparison with a 100 base pair (bp) DNA ladder (Pharmacia).

Analysis of nucleotide sequences and primers selection for the nested-PCR - Amplicon nucleotide sequences from the HCPS P and GenBank sequences of S segment from Hantaan virus (U37768), Andes virus (AF325966), Sin Nombre virus (L37904), Laguna Negra virus (AF005727), Rio Mamoré virus (U52136), Araraquara virus (AF307325), and Castelo dos Sonhos virus (AF307324) were aligned by the Higgins and Sharp algorithm, using default stringency parameters as recommended by the DNASIS for Windows version 2.10 software (Hitachi, Japan). Nested-PCR internal primers (SAHNinternal-S and SAHNinternal-C) shown in Table II were chosen from the aligned nucleotide sequences in high homology regions and matching between nucleotides 277 to 298 and 391 to 414 to produce a $140 \mathrm{bp}$ amplicon. The phylogenetic analysis of the aligned nucleotide sequences of patient samples was performed using the same software, by applying the UPGMA method (Unweighted Pair Group Method with Arithmatic Mean).

Nested-PCR - Nested-PCR was carried out starting with $2 \mu \mathrm{l}$ of the amplicons obtained in the first round of RT-PCR in a reaction mixture including $1 \mathrm{U}$ of thermostable Taq DNA polymerase (Pharmacia), $5 \mu$ l of $10 \mathrm{x}$ buffer, $0.3 \mu \mathrm{M}$ of each SAHNinternal-C and SAHNinternal-S primer, and DEPC treated water completing a $50 \mu \mathrm{l}$ volume. Twenty-five cycles of amplification were performed with the same parameters as for the first round of PCR.

Nucleotide sequencing of RT-PCR and nested PCR amplicons - The 264 bp amplicons from RT-PCR were subjected to 25 re-amplification cycles of $\mathrm{PCR}$ at $95^{\circ} \mathrm{C}$ for $30 \mathrm{~s}$, $55^{\circ} \mathrm{C}$ for $45 \mathrm{~s}$, and $72^{\circ} \mathrm{C}$ for $180 \mathrm{~s}$. The amplicons were purified using Wizard PCR preps (Promega, US) and $7.5 \mu \mathrm{l}$ of the purified DNAs were sequenced with the Thermo Sequenase CY5.5 terminator kit (Amersham-Pharmacia, England), using $1 \mu \mathrm{M}$ of each SAHN-C and SAHN-S primers and fluorescein labeled nucleotides. The products were run in a denaturing polyacrylamide sequencing gel in a personal seq 4 x 4 sequencer (Pharmacia), for $35 \mathrm{~min}$.
One 140 bp amplicon from P-2, obtained by nestedPCR, was sequenced as described above. This amplicon was selected because it was not possible to obtain the 264 bp amplicon of P-2 in the RT-PCR.

\section{RESULTS}

$R T$-PCR - Amplicons of approximately 264 base pairs (bp) were obtained at the first round of PCR from eight out of nine blood samples from HCPS patients $(88.9 \%$ positivity, Fig. 1A). Amplicons of approximately $140 \mathrm{bp}$ were obtained by nested-PCR from all blood samples (Fig. 1B). The negative control blood sample of the patient infected with dengue was tested by RT-PCR and by nested PCR without showing amplicon.

Nucleotide sequences - The alignment of nucleotide sequences of the eight amplicons obtained by RT-PCR and one amplicon obtained by nested-PCR, showed matching percentages from 94.8 to $100 \%$ among themselves. The nine amplicons also showed $82.6 \%$ matching with Andes virus, $78.4 \%$ with Rio Mamoré virus and Laguna Negra virus, and $98.6 \%$ with Araraquara virus, as shown in the dendrogram at Fig. 2. These nine amplicons from HCPS patient blood samples are highly homologous and probably belong to Araraquara virus or a very close related virus, as shown in Fig. 3.

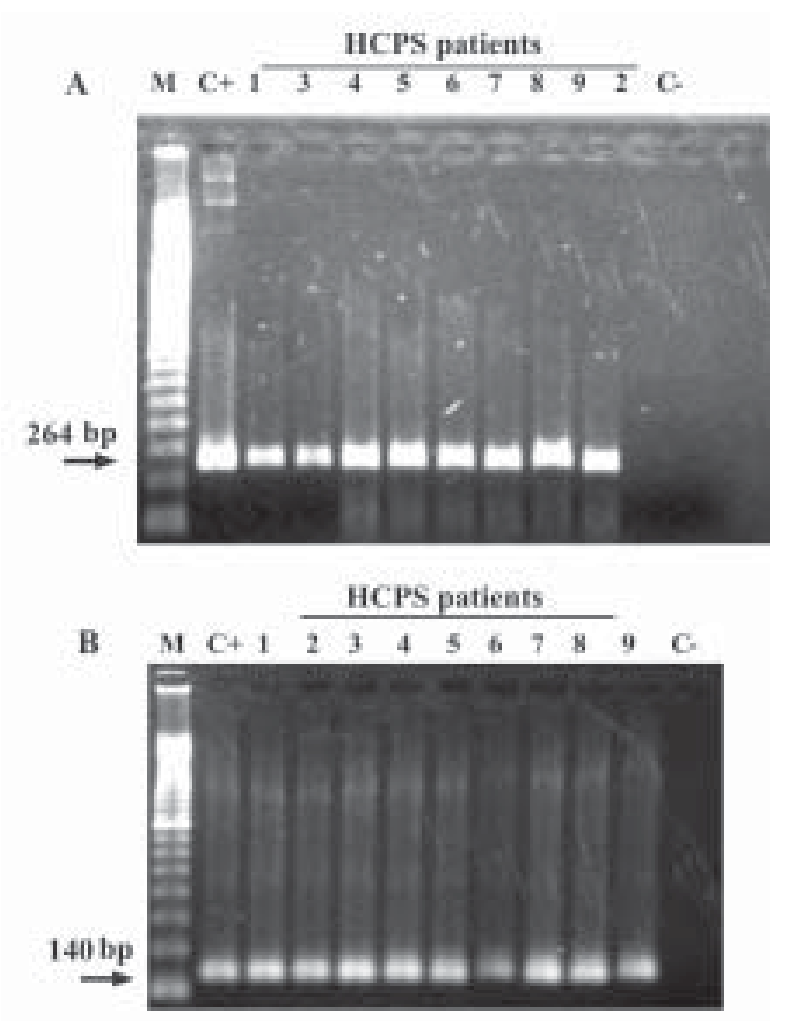

Fig. 1A: agarose gel showing amplicons having 264 bp obtained in the reverse transcription polymerase chain reaction from the sera of eight of nine hantavirus cardiopulmonary syndrome (HCPS) patients (P1; P3-P9); the amplicon from patient 2 (P-2) was not detectable. In both gels ( $\mathrm{A}$ and $\mathrm{B}$ ), a plasmid containing the $\mathrm{N}$ gene of Andes virus was used as positive control $(\mathrm{C}+)$. The serum from one patient with dengue was used as negative control (C-); B: agarose gel showing amplicons having $140 \mathrm{bp}$ obtained in the nestedPCR from the sera of all nine HCPS patients. 


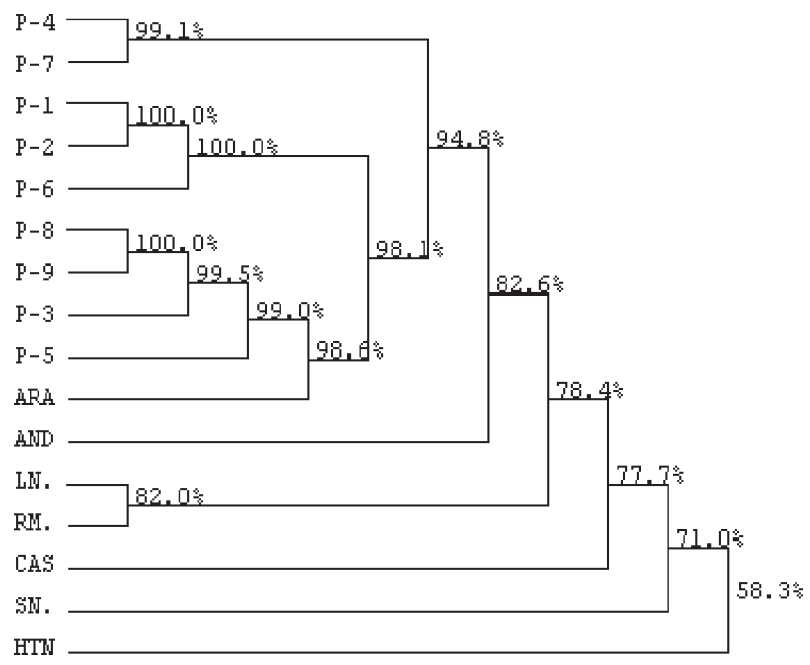

Fig. 2: phylogenetic dendogram of nucleotide sequences of eight amplicons obtained by reverse transcription polymerase chain reaction (P1; P3-P9) and one amplicon obtained by nested-PCR (P2) from nine hantavirus cardiopulmonary syndrome patients, showing Araraquara virus (ARA) in the same branch. Laguna Negra (LN), Rio Mamore (RM), Andes (AND) also South American hantaviruses clustered in a different branch. Castelo dos Sonhos (CAS), Sin Nombre (SN) and Hantaan (HTN) viruses were more distantly localized in the phylogenetic dendogram. Calculated matching percentages are indicated at each branching point of the dendogram.

\section{DISCUSSION}

In this study, the RNA extracts from which hantavirus genome was amplified by nested-PCR came from stored whole hemolyzed blood samples collected from HCPS patients between 3 and 15 days of disease. It is remarkable that some of the samples were frozen and thawed two or three times. This suggests that this kind of sample is suitable for hantavirus genome detection by RT-PCR and that the Tryzol-LS (Gibco, US) method modified by Bowen et al. (1997) is adequate for RNA extraction from this kind of clinical sample.

The efficacy of SAHN-C and SAHN-S primers selected on the basis of sequence similarity in the $\mathrm{N}$ gene among Andes, Rio Mamoré, Araraquara, and Castelo dos Sonhos, all South American hantaviruses was tested for the amplification of Brazilian hantavirus genome in HCPS patients. The RT-PCR with SAHN-C and SAHN-S primers was able to amplify the hantavirus genomes in $88.9 \%$ of the tested blood samples of HCPS patients. Amplicon was not obtained in the RT-PCR and the nested-PCR from a blood sample of one patient with dengue and one water sample. The specificity of the amplicons was confirmed by the high matching percentages of their nucleotide sequences with that of Araraquara virus (94.8\% to $99.1 \%$ ).

In order to further enhance sensitivity a round of nested-PCR was added using primers SAHNinternalC and SAHNinternalS, selected of highly conserved regions present in hantaviral S segments internally to the RT-PCR amplicons from HCPS patients and Araraquara virus. Based on the results obtained, despite of the restricted number of HCPS tested blood samples this nested RTPCR assay seems to be accurate and suitable for clinical use, at least in the northeastern region of the state of São Paulo, Brazil.
The nucleotide sequences of the $\mathrm{N}$ genes of hantavirus amplicons obtained by RT-PCR showed high homology with those of several South American hantaviruses. The highest matchings (94.8\% to $99.1 \%)$ were observed with the Araraquara virus that is shown in Fig. 2 surrounded by the HCPS patients samples. This result was expected because the genome of Araraquara virus was obtained in 1996 from a HCPS patient living in Araraquara City, approximately $90 \mathrm{~km}$ of Ribeirão Preto (Johnson et al. 1999). Interestly, HCPS P-1 and P-2 showed highest matching between themselves. This fact could be explained because these patients lived in the same place. Thus, we believe this virus is the causative agent of HCPS in the region of Ribeirão Preto. The other South American hantaviruses, were detected in places over $1600 \mathrm{~km}$ from Ribeirão Preto and clustered in a separate branch of the phylogenetic tree (Fig. 2), showing 82.6\% (Andes) and 78.4\% (Laguna Negra and Rio Mamoré) of homology with the hantaviruses from Ribeirão Preto associated to HCPS.

The nested-PCR with SAHN internal primers was found to be suitable for diagnosis because it detected the hantavirus genome in all the HCPS blood samples. Besides, false-positive results associated to sample contamination were not observed. Amplicons were not obtained from water or from the blood sample of the patient with dengue, as shown in Fig. 1B.

In short, this nested RT-PCR could be used as a diagnostic test of hantavirus infection. Additionally, the RTPCR method could be used for the amplification of the entire $\mathrm{N}$ gene of the hantavirus contained in the blood sample of HCPS cases. This gene could be cloned and expressed in order to produce a recombinant $\mathrm{N}$ protein from the entire gene obtained from blood sample patients, that could be used for one more specific-ELISA This approach could be a suitable alternative for enhancing sensitivity and specificity of the serologic test diagnosis in Brazil, using local antigens. In Brazil, ELISA is performed using American and Argentinean recombinant antigens.

Hantavirus in Brazil is becoming a public health problem since there have been more than three hundred HCPS reported cases, and the number is constantly increasing. Besides, other clinical presentations of hantavirus infections have probably occurred in the Northeast and South regions of Brazil (Hindrichsen et al. 1993, Flores SCC, state of Santa Catarina Health Ministry, pers. commun. 2001). For addition, high levels of antibodies to hantavirus in health populations have been reported in Brazil (Holmes et al. 2000). The use of a nested RT-PCR method approach for hantavirus in Brazil would provide an early rapid diagnosis of acute hantavirus disease as well as alternative for initial characterization of genomes of hantaviruses based on the nucleotide sequence of the amplicons obtained in this nested RT-PCR. Additionally, this nested RT-PCR method may provide an important and usefull tool to improve public health system preparedness.

\section{ACKNOWLEDGEMENT}

To Dr Eurico Arruda and Dr Victor Hugo Aquino (University of São Paulo, Ribeirão Preto, Brazil) for reviewing the manuscript. 


\begin{tabular}{|c|c|c|c|c|c|c|c|}
\hline & & 10 & 20 & 30 & 40 & 50 & \\
\hline ARA & 1 & TTGAGCCTGA & TGACCATCTA & AAGGAGAAAT & CATCACTGAG & ATATGGGAAT & 50 \\
\hline $\mathrm{P}-1$. & 1 & $\ldots \ldots \ldots$ & $\ldots \ldots \ldots \ldots$ & $\ldots \ldots \ldots \ldots$ & $\ldots \ldots \ldots$ & $\ldots \ldots \ldots$ & 50 \\
\hline $\mathrm{P}-2$. & 1 & ---ー-ー--- & ---------- & --------- & --------- & ---------- & 50 \\
\hline $\mathrm{P}-3$ & 1 & $\cdots \ldots \ldots$ & $\ldots \ldots \ldots$ & $\ldots \ldots \ldots$ & $\ldots \ldots \ldots$ & $\ldots \ldots \ldots$ & 50 \\
\hline $\mathrm{P}-4$. & 1 & $\ldots \ldots \ldots$ & $\ldots \ldots \ldots$ & $\ldots \ldots \ldots$ & $\ldots \ldots \ldots$ & $\ldots \ldots \ldots$ & 50 \\
\hline $\mathrm{P}-5$. & 1 & $\ldots \ldots \ldots$ & $\ldots \ldots \ldots$ & $\ldots$..... &.$G \ldots \ldots$ & $\ldots \ldots \ldots$ & 50 \\
\hline $\mathrm{P}-6$. & 1 & $\ldots \ldots \ldots$ & $\ldots \ldots$ & $\ldots \ldots \ldots$ & $\ldots \ldots \ldots$ & $\ldots \ldots \ldots$ & 50 \\
\hline $\mathrm{P}-7$. & 1 & $\ldots \ldots \ldots$ & $\ldots \ldots \ldots$ & $\ldots \ldots \ldots$ & $\ldots \ldots \ldots$ & $\ldots \ldots \ldots$ & 50 \\
\hline $\mathrm{P}-8$. & 1 & $\ldots \ldots \ldots$ & $\ldots \ldots \ldots$ & $\ldots \ldots$.... & $\ldots \ldots \ldots$ & $\ldots \ldots \ldots$ & 50 \\
\hline$P-9$. & 1 & $\cdots \cdots{ }_{60}$ & $\cdots \cdots$ & $\begin{array}{r}\cdots \\
80\end{array}$ & $\cdots \cdots$ & $\begin{array}{r}\cdots \cdots \\
\\
100\end{array}$ & 50 \\
\hline ARA & 51 & GTGCTGGATG & TTAACССТАТ & CGATCTTGAA & GAGCCAAGTG & GCCAGACAGC & 100 \\
\hline $\mathrm{P}-1$. & 51 & $\ldots \ldots \ldots$ &.$C \ldots \ldots$ & $\ldots \ldots \ldots$ & $\ldots \ldots \ldots$ & $\ldots \ldots \ldots$ & 100 \\
\hline $\mathrm{P}-2$. & 51 & $\ldots \ldots \ldots$ &.$c \ldots \ldots$ & $\ldots \ldots \ldots$ & $\ldots \ldots \ldots$ & $\ldots \ldots \ldots$ & 100 \\
\hline $\mathrm{P}-3$. & 51 & $\ldots \ldots \ldots$ &.$C \ldots \ldots$ & $\ldots \ldots \ldots$ & $\ldots \ldots \ldots$ & $\ldots \ldots \ldots$ & 100 \\
\hline $\mathrm{P}-4$. & 51 & $\ldots \ldots \ldots$ & $\ldots$..... & $\ldots \ldots \ldots$ & $\ldots \ldots$.... &. G.CA.... & 100 \\
\hline $\mathrm{P}-5$. & 51 & $\ldots \ldots \ldots$ &.$C \ldots \ldots$ & $\ldots \ldots \ldots$ & $\ldots \ldots \ldots$ & $\ldots \ldots \ldots$ & 100 \\
\hline $\mathrm{P}-6$. & 51 & $\ldots \ldots \ldots$ &.$c \ldots \ldots$ & $\ldots \ldots \ldots$ & $\ldots \ldots \ldots$ & $\ldots \ldots \ldots$ & 100 \\
\hline $\mathrm{P}-7$. & 51 & $\ldots$ A. A... & $\ldots \ldots$ T... & $\ldots \ldots \ldots$ & $\ldots \ldots c \ldots$ & $. \mathrm{G} . \mathrm{CA} \ldots$... & 100 \\
\hline $\mathrm{P}-8$. & 51 & $\ldots \ldots \ldots$ & $. C \ldots .$. & $\ldots \ldots \ldots$ & $\ldots \ldots \ldots$ & $\ldots \ldots \ldots$ & 100 \\
\hline$P-9$. & 51 & $\cdots \cdots \cdots$ & $\begin{array}{r}. C \ldots \\
120\end{array}$ & $\begin{array}{r}\cdots \\
\quad 130\end{array}$ & $\cdots \cdots$ & $\begin{array}{r}\cdots \\
150\end{array}$ & 100 \\
\hline ARA & 101 & AGACTGGAAG & GCAATTGGGG & СТTACATCTT & GGGTTTTGCA & АТСССТАTTA & 150 \\
\hline $\mathrm{P}-1$. & 101 & $\ldots \ldots \ldots$ & $\ldots \ldots A$ & $\ldots \ldots \ldots$ & $\ldots \ldots \ldots$ & $\ldots \ldots \ldots$ & 150 \\
\hline $\mathrm{P}-2$. & 101 & $\ldots \ldots \ldots$ & $\ldots \ldots$... & $\ldots \ldots \ldots$ & $\ldots \ldots \ldots$ & $\ldots \ldots \ldots$ & 150 \\
\hline $\mathrm{P}-3$. & 101 & $\ldots \ldots \ldots$ & $\ldots \ldots \ldots$ & $\ldots \ldots \ldots$ & $\ldots \ldots \ldots$ & $\ldots \ldots \ldots$ & 150 \\
\hline $\mathrm{P}-4$. & 101 & $\ldots \ldots \ldots$ & $\ldots \ldots A$ & $\ldots \ldots \ldots$ & $\ldots \ldots \ldots$ & $\ldots \ldots \ldots$ & 150 \\
\hline $\mathrm{P}-5$. & 101 & $\ldots \ldots \ldots$ & $\ldots \ldots \ldots$ & $\ldots \ldots \ldots$ & $\ldots \ldots \ldots$ & $\ldots \ldots \ldots$ & 150 \\
\hline $\mathrm{P}-6$. & 101 & $\ldots \ldots \ldots$ & $\ldots \ldots A$ & $\ldots \ldots \ldots$ & $\ldots \ldots \ldots$ & $\ldots \ldots \ldots$ & 150 \\
\hline $\mathrm{P}-7$. & 101 & $\ldots \ldots \ldots$ & $\ldots \ldots A$. & $\ldots \ldots \ldots$ & $\ldots \ldots \ldots$ & $\ldots \ldots \ldots$ & 150 \\
\hline $\mathrm{P}-8$. & 101 & $\ldots \ldots \ldots$ & $\ldots \ldots \ldots$ & $\ldots \ldots \ldots$ & $\ldots \ldots \ldots$ & $\ldots \ldots \ldots$ & 150 \\
\hline$P-9$. & 101 & $\begin{array}{r}\cdots \\
160\end{array}$ & $\cdots \cdots \cdots$ & $\begin{array}{r}\cdots \\
\quad 180\end{array}$ & $\cdots \cdots \cdots$ & $\cdots \cdots{ }_{200}$ & 150 \\
\hline$A R A$ & 151 & TACTAAAGGC & СTTATATATG & CTGTCAACTC & GTGGAAGGCA & GACAGTGAAG & 200 \\
\hline $\mathrm{P}-1$. & 151 & $\ldots \ldots \ldots$ & $\ldots \ldots \ldots$ & $\ldots \ldots \ldots$ & $\ldots \ldots \ldots$ & $\ldots \ldots \ldots$ & 200 \\
\hline $\mathrm{P}-2$. & 151 & $\ldots \ldots{ }^{-----}$ & ----------- & ---------- & ---------- & ---------- & 200 \\
\hline $\mathrm{P}-3$. & 151 & $\ldots \ldots \ldots$ & $\ldots \ldots \ldots$ & $\ldots \ldots \ldots$. & $\ldots \ldots \ldots$ & $\ldots \ldots \ldots$ & 200 \\
\hline $\mathrm{P}-4$. & 151 & $\ldots \ldots \ldots$ & $\ldots \ldots \ldots$ & $\ldots \ldots \ldots$ & $\ldots \ldots \ldots$ & $\ldots \ldots$. . . & 200 \\
\hline $\mathrm{P}-5$. & 151 & $\ldots \ldots \ldots$ & $\ldots \ldots \ldots$ & $\ldots \ldots \ldots c$ & $\ldots \ldots \ldots$ & $\ldots \ldots \ldots$ & 200 \\
\hline $\mathrm{P}-6$. & 151 & $\ldots \ldots \ldots$ & $\ldots \ldots \ldots$ & $\ldots \ldots \ldots$ & $\ldots \ldots \ldots$ & $\ldots \ldots \ldots$ & 200 \\
\hline $\mathrm{P}-7$. & 151 & $\ldots \ldots \ldots$ & $\ldots \ldots \ldots$ & $\ldots \ldots \ldots$ & $\ldots \ldots \ldots$ & ....... & 200 \\
\hline $\mathrm{P}-8$. & 151 & $\ldots \ldots \ldots$ & $\ldots \ldots \ldots$ & $\ldots \ldots . c$ & $\ldots \ldots \ldots$ & $\ldots \ldots \ldots$ & 200 \\
\hline$P-9$. & 151 & $\cdots \cdots{ }_{210}$ & $\cdots \cdots{ }_{220}$ & $\cdots{ }_{230}$ & $\cdots \cdots$ & $\cdots \cdots$ & 200 \\
\hline ARA & 201 & GACAACAAGG & GCACTAGGAT & AAGGTTCAAG & GATGATTCA. & $\ldots \ldots \ldots$ & 250 \\
\hline $\mathrm{P}-1$. & 201 & $\ldots \ldots \ldots$ & $\ldots \ldots \ldots$ & $\ldots \ldots \ldots$ & $\ldots \ldots \ldots$ & $\ldots \ldots \ldots$ & 250 \\
\hline $\mathrm{P}-2$. & 201 & ---------- & ---------- & ----------- & --------- & $\ldots \ldots \ldots$ & 250 \\
\hline $\mathrm{P}-3$. & 201 & $\ldots \ldots \ldots$ & $\ldots \ldots \ldots$ & $\ldots \ldots \ldots$ & $\ldots \ldots \ldots$ & $\ldots \ldots \ldots$ & 250 \\
\hline $\mathrm{P}-4$. & 201 & $\ldots \ldots \ldots$ & $\ldots \ldots \ldots$ & $\ldots \ldots \ldots$ & $\ldots \ldots \ldots$ & $\ldots \ldots \ldots$ & 250 \\
\hline $\mathrm{P}-5$. & 201 & $\ldots \ldots \ldots$ & $\ldots \ldots \ldots$ & $\ldots \ldots \ldots$ & $\ldots \ldots \ldots$ & $\ldots \ldots \ldots$ & 250 \\
\hline $\mathrm{P}-6$. & 201 & $\ldots \ldots \ldots$ & $\ldots \ldots \ldots$ & $\ldots \ldots \ldots$ & $\ldots \ldots \ldots$ & $\ldots \ldots \ldots$ & 250 \\
\hline $\mathrm{P}-7$. & 201 & $\ldots \ldots \ldots$ & $\ldots \ldots \ldots$ & $\ldots \ldots \ldots$ & $\ldots \ldots \ldots$ & $\ldots \ldots \ldots$ & 250 \\
\hline $\mathrm{P}-8$. & 201 & $\cdots \ldots \ldots$ & $\ldots \ldots \ldots$ & $\ldots \ldots \ldots$ & $\ldots \ldots \ldots$ & $\ldots \ldots \ldots$ & 250 \\
\hline $\mathrm{P}-9$. & 201 & $\ldots \ldots \ldots$ & $\ldots \ldots \ldots$ & $\ldots \ldots \ldots$ & $\ldots \ldots \ldots$ & $\ldots \ldots \ldots$ & 250 \\
\hline
\end{tabular}

Fig. 3: alignment by the Higgins and Sharp algorithm of eight amplicon nucleotide sequences obtained by reverse transcription polymerase chain reaction (P-1; P3-P9) and one amplicon obtained only by nested-PCR (P2) from hantavirus cardiopulmonary syndrome patients, also including the nucleotide sequence of the $\mathrm{S}$ segment of Araraquara virus (ARA).

\section{REFERENCES}

Bharadwaj M, Botten J, Torrez-Martinez N, Hjelle B 1997. Rio Mamore virus: genetic characterization of a newly recognized hantavirus of the pygmy rice rat, Oligorizomys microtis, from Bolivia. Am J Trop Med Hyg 57:368-374.
Bowen MD, Peters CJ, Nichol ST 1997. Phylogenetic analysis of the Arenaviridae: patterns of virus evolution and evidence for coespeciation between arenaviruses and their rodent hosts. Mol Phylogenet Evol 8: 301-316.

Figueiredo LTM, Moreli ML, Kashima S, Almeida VSO, Félix 
PC, Bruno JC, Ferreira IV, Mançano FD 1999. Hantavirus pulmonary syndrome (HCPS) in Guariba, SP, Brazil. Report of 2 cases. Rev Inst Med Trop São Paulo 41: 131137.

Fulhorst CF, Monroe MC, Salas RA, Duno G, Utrera A, Ksiazek TG, Nichol ST, Manzione NMC, Tovar D, Tesh RB 1997. Isolation, characterization, and geographic distribution of Caño Delgadito virus, a newly discovered South American hantavirus (family Bunyaviridae). Virus Res 51: 159-171.

Funasa, Ministry of Health 2003. Report on Hantavirus Pulmonary Syndrome Cases until December, Brasilia.

Garin D, Peyrefitte C, Crance JM, Faou AL, Jouan A, Bouloy M 2001. Highly sensitive Taqman PCR detection of Puumala hantavirus. Microbes Infect 3: 739-745.

Hindrichsen S, Medeiros de Andrade A, Clement J, Leirs H, Mc Kenna P, Mattys P, Neild GH 1993. Hantavirus infection in Brazilians patients from Recife with suspected leptospirosis. Lancet 341: 8836-8850.

Holmes RR, Boccanera R, Figueiredo LTM, Mançano SR, Pane C 2000. Seroprevalence of human Hantavirus infection in the Ribeirão Preto region of São Paulo state, Brazil. Emerg Infect Dis 6: 5-6.

Iversson L 1996. Doença humana por hantavirus. In R Veronesi, R Focaccia (eds), Tratado de Infectologia, Atheneu, São Paulo, p. 219-228

Johnson AM, Bowen MD, Ksiazek TG, Williams RJ, Bryan RT, Mills JN, Peters CJ, Nichol ST 1997. Laguna Negra virus associated with HPS in Western Paraguay and Bolivia. Virology 238: 115-127.

Johnson AM, Souza LTM, Ferreira IB, Pereira LE, Ksiazek TG, Rollin PE, Peters CJ, Nichol ST 1999. Genetic investigation of novel hantaviruses causing fatal HPS in Brazil. $J$ Med Virol 59: 527-535.

Kim EC, Kim IS, Choi Y, Kim SG, Lee JS 1994. Rapid differentiation between Hantaan and Seoul viruses by polymerase chain reaction and restriction enzyme analysis. J Med Virol 43: 245-248.

Ksiasek TG, Peters CJ, Rollin PE, Zaki SR, Nichol ST, Spiropoulou C, Morzunov S, Feldman H, Sanches A, Khan AS, Mahy BWJ, Waschsmuth K, Butler JC 1995. Identification of a new North American hantavirus that causes acute pulmonary syndrome in Argentina. Virology 220: 223-226.

Le Guenno B 1993. Identifying a hantavirus associated with acute respiratory illness: a PCR victory? Lancet 342: 14381439.

Lopez N, Padula P, Rossi C, Miguel S, Edelstein A, Ramirez E, Franze-Fernandez MT 1997. Genetic characterization and phylogeny of Andes virus and variants from Argentina and Chile. Virus Res 50: 77-84.

LeDuc JW, Smith GA, Pinheiro FP, Vasconcelos PFC, Rosa EST, Maiztegui J 1985. Isolation of a Hantaan-related virus from Brazilian rats and serologic evidence of its widespread distribution in South America. Am J Trop Med Hyg 34: 810-815.

Nichol ST, Spiropoulou CF, Morzunov S, Rolling PE, Ksiazek TG, Feldmann H, Sanchez A, Childs J, Zaki S, Peters CJ 1993. Genetic identification of a hantavirus associated with an outbreak of acute respiratory illness. Science 262: 914917.

Padula PJ, Colavecchia SB, Martínez VP, Gonzalez DVMO, Edelstein A, Miguel SDL, Russi J, Mora Riquelme J, Colucci N, Almirón M, Rabinivich RD 2000a. Genetic diversity, distribution, and serological features of hantavirus infection in five countries in South America. J Clin Microbiol 38: 3029-3035.

Padula PJ, Rossi CM, Della Valle MO, Martinez PV, Colavecchia SB, Edelstein A, Miguel SD, Rabinovich RD, Segura EL 2000b. Development and evaluation of a solid-phase enzyme immunoassay based on Andes hantavirus recombinant nucleoprotein. J Med Microbiol 49: 149-155.

Schmaljohn C, Hjelle B 1997. Hantaviruses: a global disease problem. Emerg Infect Dis 3: 95-104.

Schmaljohn CS 1996. Bunyaviridae. The viruses and their replication. In BN Fields, DM Knipe, PM Howley (eds), Fundamental Virology, 3rd ed., Lipincott-Raven, Philadelphia, p. 649-673.

Wells RM, Estani SS, Yadon ZE 1997. An unusual outbreak in Southern Argentina: person to person transmission? Emerg Infect Dis 3: 171-174.

Zaki SR, Greer PW, Coffield LM, Goldsmith CS, Nolte KB, Foulcar K, Feddersen RM, Zumwalt RE, Miller L, Khan AS, Rollin PE, Ksiazek TG, Nichol ST, Mahy BWJ, Peters CJ 1995. Hantavirus pulmonary syndrome. Pathogenesis of an emerging infectious disease. Am J Pathol 146: 552579.

Zhao X, Hay J 1997. The evolution of hantaviruses. Immunol Invest 26: 191-197. 